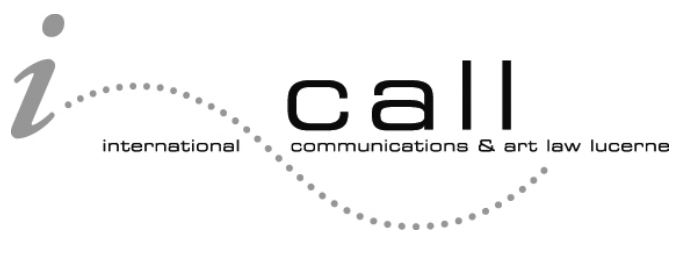

\title{
Internet Creativity, Communicative Freedom and a Constitutional Rights Theory Response to "Code is Law"
}

\author{
Christoph B. Graber*
}

NOVEMBER 2010

\begin{abstract}
The code that regulates cyberspace empowers private bodies to set standards of Internet access and use, which are often not visible. Content filtering, as a response to copyright infringement, or models differentiating between various data transmissions are examples of measures that have been undertaken by Internet intermediaries. Arguably, they are necessary to protect intellectual property and digital business. Emanating from private bodies, such measures are beyond the reach of constitutional rights, although they may strongly impact conditions of communicative freedom and creativity on the Internet. This paper endeavours to explore whether a theory of "constitutional rights in the private sphere" may have a case in a digital networked ecology.
\end{abstract}

\section{KEY WORDS}

Content filtering, copyright, Internet creativity, communicative freedom, constitutional rights.

\footnotetext{
* Christoph B. Graber is Professor of Law and head of the i-call (International Communications and Art Law Lucerne) research centre, at the University of Lucerne. The author would like to thank William Gallagher, Shubha Ghosh, Peter Yu and Thomas Steiner for comments on an earlier draft of the paper.
}

I-CALL WORKING PAPERS are the result of research that takes place through the i-call research centre. The papers have been peer-reviewed.

Suggested Citation: Christoph B. Graber, 'Internet Creativity, Communicative Freedom and a Constitutional Rights Theory Response to "Code is Law"', i-call Working Paper No. 03 (2010), Lucerne, Switzerland: University of Lucerne. 
Published by:

i-call, The Research Centre for International Communications and Art Law at the University of Lucerne

Hofstrasse 9

P.O. Box 7464

6000 Lucerne 7

Switzerland

ISSN 1664-0144

(C) The i-call Research Centre, Switzerland

All rights reserved. No part of this publication may be reproduced, stored in a retrieval system, or transmitted in any form or by any means, mechanical, photocopying, recording or otherwise, without prior written permission of the publisher.

Permission to use this content must be obtained from the copyright owner. 
INTERNET CREATIVITY, COMMUNICATIVE FREEDOM AND A CONSTITUTIONAL RIGHTS THEORY RESPONSE TO “CODE IS LAW"

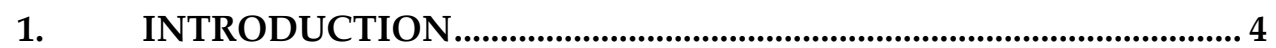

2. PRIVATE REGULATION OF INTERNET SPEECH............................ 7

2.1 PARADIGM CHANGE IN COPYRIGHT ENFORCEMENT .............................. 7

2.2 CONSEQUENCES OF THE NEW PARADIGM FROM A COMMUNICATIVE FREEDOM PERSPECTIVE ................................................................... 10

3. CREATIVITY, COMMERCIAL INTERESTS AND COMMUNICATIVE FREEDOM IN A CONSTITUTIONAL SETTING.

3.1 The Participative Web and the Change of Communicative

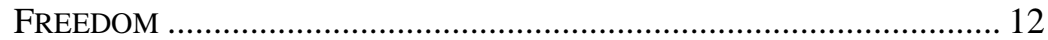

3.2 COMMUNICATIVE FREEDOM AND THE NETWORK GRID ....................... 15

4. CONSTITUTIONAL RIGHTS IN THE PRIVATE SPHERE OF THE INTERNET ......................................................................................... 17

5. IMPLEMENTING COMMUNICATIVE FREEDOM ON THE

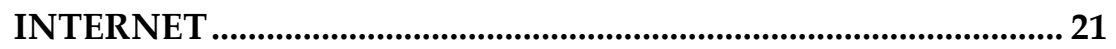

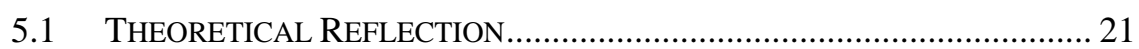

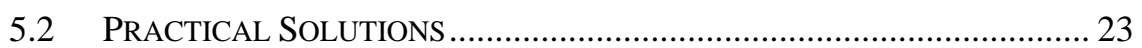

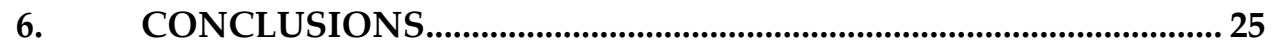




\section{INTRODUCTION}

"Code is law" is the famous formula coined by Lawrence Lessig to describe that the technological architecture of the Internet functions as a regulator - in addition to state law, social norms and the market. ${ }^{1}$ Joel Reidenberg was one of the first to emphasise that the technological architecture of the network imposes rules on access and use of information. ${ }^{2}$

Technological architectures may prohibit certain actions on the network, such as access without security clearances, or may impose certain flows, such as mandatory address routing data for electronic messages. Technology may also offer policymakers a choice of information flow rules through configuration decisions.

Reidenberg called these rules Lex Informatica. Accordingly, Lex Informatica is a rule system that is embedded in technological standards and that exists parallel to the law of the state. ${ }^{3}$

For many lawyers it is difficult to accept that code fulfils regulatory functions which are similar to the law of the state. This is due to an understanding of regulation that is based on John Austin's state-centred concept of the law. ${ }^{4}$ For Austin, "all law derives directly or indirectly from the state". ${ }^{5}$ According to this concept, the law can be recognised by the way it is enacted and enforced. Law is enacted by an elected legislative body that observes prescribed procedures and it is enforced through the threat of state sanctions. ${ }^{6}$ This theory of law as "commands backed by threats" is not of much use on the Internet. In cyberspace, an Austinian concept of law is too limited and a two-step enlargement would be necessary.

First, it should be expanded from narrow state-centrism towards the inclusion of social norms and other private forms of regulation. Such a concept of lebendes Recht (living law) was postulated by Eugen Ehrlich already at the beginning of the 20th century. ${ }^{7}$ Similarly, Niklas Luhmann's concept of law is not limited to state law but includes regulations that emanate from private entities as well. ${ }^{8}$ On the Internet, living law is omnipresent, for instance in self-regulatory activities of net communities

1 Lawrence Lessig, Code and other Laws of Cyberspace, New York, USA: Basic Books, 1999. Lawrence Lessig, 'Code is Law. On Liberty in Cyberspace' (January-February 2000) Harvard Magazine, available online at http://harvardmagazine.com/2000/01/code-is-law.html (all online sources were accessed 25 September 2010).

2 Joel R. Reidenberg, 'Lex Informatica: The Formulation of Information Policy Rules Through Technology' (1998) Texas Law Review, 76, pp. 553-584, at p. 568. See also Joel R. Reidenberg, 'Governing Networks and Rule-Making in Cyberspace' (1996) Emory Law Journal, 45, pp. 911-930.

3 Reidenberg, 'Lex Informatica: The Formulation of Information Policy Rules Through Technology', supra note 2 , at pp. 568-569.

4 John Austin, The Province of Jurisprudence Determined (1832), reprinted in London: Weidenfeld \& Nicolson, 1954.

5 Roger Cotterrell, The Sociology of Law. An Introduction, 2nd edn, London: Butterworths, 1992, at p. 26.

6 Austin, supra note 4, at pp. 13-20.

7 Eugen Ehrlich, Fundamental Principles of the Sociology of Law, translation by Walter L. Moll, New Brunswick: Transaction Publishers, 2002 (first published 1913 in German, 1936 in English), at pp. 486-498.

$8 \quad$ Niklas Luhmann, Law as a Social System, translation by Klaus A. Ziegert, Oxford: Oxford University Press, 2004, at pp. 291-296. 
such as the exclusion of misbehaving participants from a chat forum or a multiplayer online game, ${ }^{9}$ or where Internet Service Providers (ISPs) administer blacklists of servers disseminating spam-containing electronic mail. ${ }^{10}$ More recent examples - that will be further discussed below - include Internet intermediaries throttling peer-topeer (P2P) traffic in order to reserve bandwidth for the distribution of more lucrative content 11 or agreements between the entertainment industry and Internet intermediaries to fight copyright piracy by the means of filtering technology. ${ }^{12}$

Second, a more thorough understanding of how technology regulates behaviour on the Internet would be necessary. Lessig's formula "code is law" suggesting that "law" and "code" are identical is more appealing than precise. A close reading of Lessig's writings reveals however, that he does not equalise "law" and "code" as the formula would suggest. Lessig rather defines "code" as a form of co-action between software and hardware on the Internet constituting an architecture of technology. ${ }^{13}$

We are coming to understand a newly powerful regulator in cyberspace. ... This regulator is what I call "code" - the instructions embedded in the software or hardware that makes cyberspace what it is. This code is the "built environment" of social life in cyberspace. It is its "architecture".

This architecture of technology is a structure that conditions regulation on the Internet. Hence, code does not directly regulate the Internet but pre-structures the form that regulation on the Internet may take to be effective in determining social behaviour. As Vagias Karavas observed, the main purpose for Lessig in using the formula "code is law" was to "sensitise his readers towards the fact that in the digital environment nothing is natural, as it appears to be, but instead, everything is the result of technological solutions, in other words, of the code." ${ }^{14}$ Code is so powerful because it may fulfil legislative and executive functions at the same time without being constrained by any type of a "digital separation of powers".

With regard to its legislative functions the code of cyberspace is different from the law of real space in at least one important manner. In real space, the law is a form of communication. It is deliberated over in a discursive political process and is enacted by the constitutionally competent legislative body. This is different for the code of cyberspace. Here, the actor who reigns over the architecture of technology also defines the rights and constraints existing within this architecture. Since on the Internet this actor is often a private company, this raises serious concerns from a constitutional perspective.

9 See Gregory Lastowka and Dan Hunter, 'Virtual Worlds. A Primer', in Jack Balkin and Beth Simone Noveck (eds), The State of Play. Law, Games and Virtual Worlds, New York: New York University Press, 2006, pp. 13-28; and Vagias Karavas, 'Rechtssoziologie auf Probe', in Jürg-Beat Ackermann and Felix Bommer (eds), Liber Amicorum für Dr. Martin Vonplon, Zürich: Schulthess, 2009, pp. 193-202, at p. 194.

10 See Lawrence Lessig, Code Version 2.0, New York: Basic Books, 2006, at p. 112.

11 Sonia K. Katyal, 'Filtering, Piracy, Surveillance and Disobedience' (2009) The Columbia Journal of Law and the Arts, 32 (4), pp. 401-426, at pp. 420-421.

12 Infra, note 34 , and accompanying text.

13 Lessig, 'Code Version 2.0', supra note 10, at p. 121.

14 Vagias Karavas, 'Governance of Virtual Worlds and the Quest for a Digital Constitution', in Christoph Beat Graber and Mira Burri-Nenova (eds), Governance of Digital Game Environments and Cultural Diversity, Cheltenham, UK: Edward Elgar, 2010, pp. 153-169, at p. 157. 
With regard to its executive functions code is different from law since it is "selfexecutive". In real space, compliance with (state) law depends on both enforcement by state power and acceptance by the addressees of the regulation. Acceptance is a precondition for compliance not only for state law but also for social norms. ${ }^{15}$ For Lessig, "[l]aw and norms are more efficient the more subjective they are, but they need some minimal subjectivity to be effective at all."16 In cyberspace, however, the situation is different. Effects of code are not dependent on enforcement at all, nor is there any subjective constraint. The code of cyberspace even works when the person constrained does not know that the constraint exists. This is due to self-execution, which is a key feature of the technological architecture of the Internet. ${ }^{17}$

Lessig uses the example of copyright protection in Second Life to better explain how code executes itself independently of any threats of state sanctions or any subjective constraints. ${ }^{18}$ In real space, intellectual property (IP) legislation regulates any use a person may make of a copyright-protected work. For instance, IP legislation will decide whether a third person is allowed to take a picture of the copyright-protected sculpture in the garden of my house. In cyberspace, however, the constraint is not in the law, it is in the code. If the sculpture is in the garden of my Second Life house, then taking a picture will simply not be possible for anybody who is not in possession of a licence to do so.

Since the technological infrastructure of the Internet can be as easily manipulated by private persons as by states/governments, this poses the question of whether such private action should be subject to constitutional scrutiny. ${ }^{19}$ This paper will focus on threats to free-speech values arising from code that is controlled by private actors. More specifically, it will look at technologies that are used by private companies to filter content on the Internet in order to fight copyright piracy. Often, filter technologies rely on automated methods to detect copyright infringements and, in some cases, such interference is even not visible to the user. These are concerns that advocates of communicative freedom on the Internet should take seriously.

Filtering technologies are used by the entertainment industry in its battle against copyright infringements. The industry argues that such technologies are necessary to protect creativity on the Internet. Critics object that filtering endangers free-speech values, including user creativity. Hence, creativity is used by both sides as a catchword to defend their respective ideological standpoint. What is hidden behind ideology is a collision between economic and non-economic values. In this paper, we will argue that such a conflict of values should be discussed within a constitutional framework. Finally, the paper will explore from a transnational legal perspective whether a theory of "constitutional rights in the private sphere", as developed in a European context, might have a case in a digital networked ecology.

Locus Classicus is Eugen Ehrlich's recognition theory of law ("Anerkennungstheorie“). See Ehrlich, supra note 7, at pp. 164-167. See also Jürgen Habermas, Between Facts and Norms. Contributions to a Discourse Theory of Law and Democracy, translation by William Regh, Cambridge, MA: MIT Press, 1996, at p. 448.

16 Lessig, 'Code Version 2.0', supra note 10, at p. 344.

17 Ibid., at pp. 342-344.

$18 \quad$ Ibid., at pp. 110-111.

19 Paul S. Berman, 'Cyberspace and the State Action Debate: The Cultural Value of Applying Constitutional Norms to "Private Regulation"' (2000) University of Colorado Law Review, 71, pp. 1263-1310, at p. 1271. 


\section{Private Regulation OF INTERnet SPEeCH}

Recent developments show that threats to free-speech values on the Internet arise more often from private regulation rather than from state intervention. ${ }^{20}$ According to Hans-Jürgen Papier, president of the German Constitutional Court until March 2010 and renowned guardian of civil liberties, the basic rights of the German Grundgesetz (i.e. the German Constitution) related to the integrity and confidence in computer systems (including the Internet) today are not only threatened by the state, but also by private persons and corporations. ${ }^{21}$ What holds true for network and PC infiltration applies even more to content filtering, which is increasingly used by private entities particularly to fight copyright piracy.

\subsection{PARADIGM CHANGE IN COPYRIGHT ENFORCEMENT}

Content filtering executed by private entities is on the rise. ${ }^{22}$ According to observers, this is a consequence of a new global trend in copyright enforcement, shifting the lead management in the combat against piracy from the content owners to Internet intermediaries. The new trend started in the second half of 2007.

As a broad survey by De Beer and Clemmer shows, many industrial countries worldwide have been tightening the conditions under which ISPs and other Internet intermediaries may benefit from copyright safe harbours. ${ }^{23}$ Judicial authorities, policymakers and government lawmakers alike have been reconsidering intermediaries' responsibilities in copyright enforcement and now require them to actively fight copyright infringement in order to escape liability. The consequence is a shift in the model of copyright enforcement. Whereas, under the old model, intermediaries were only required to react ex post to a right holder's notice of copyright infringements, the new model puts them into an active role of ex ante filtering copyright infringements. This policy shift from "passive-reactive to activepreventive schemes for communication intermediaries" is mainly a result of strong lobbying by the entertainment industries, which apparently convinced many governments "of the importance of creative industries to their nations' cultural and economic well-being." ${ }^{24}$ Since the recording industries' global lawsuits have proved

20 For examples of nominally private actors wielding regulatory power on the Internet see Patricia L. Bellia, Paul S. Berman and David G. Post, Cyberlaw. Problems of Policy and Jurisprudence in the Information Age, 3rd edn, St. Paul, MN: Thomson West, 2007, at pp. 308-327.

${ }^{21}$ See interview W. Janisch and H. Kerscher, 'Verfassungsrichter Papier gegen die Totalkontrolle', Süddeutsche Zeitung (6 March 2010), available online at http://www.sueddeutsche.de/politik/1/505205/text/.

22 Content filtering relies on a technology that is known as "Deep Packet Inspection" (DPI). DPI allows the network to make decisions about how to handle a certain type of content in network data streams, including filtering or slowing down certain packets based on the recognition of a specific pattern of the datagram. For technical details see Milton Mueller, The End of the Net as we know it? Deep Packet Inspection and Internet Governance (forthcoming).

23 Jeremy De Beer, and Christopher D. Clemmer, 'Global Trends in Online Copyright Enforcement: A NonNeutral Role for Network Intermediaries?' (2009) The Journal of Law, Science and Technology, 49, pp. 375-409, at p. 376. The survey covers 12 diverse jurisdictions including Australia, Canada, China, the European Union, France, Germany, Japan, New Zealand, Singapore, South Korea, the United Kingdom and the United States.

24 De Beer and Clemmer, supra note 23, at p. 404. 
ineffective to fight piracy, ${ }^{25}$ "[c]opyright holders and governments realize that Internet intermediaries are technologically and commercially well positioned to assist with copyright enforcement. ${ }^{\prime 26}$

The "notice and takedown" framework ${ }^{27}$ of the US Digital Millennium Copyright Act (DMCA) serves well to exemplify the functioning of the old model and its eventual shift from a low standard of liability for ISPs towards enhanced liability. ${ }^{28}$ Under the DMCA, as crafted by Congress, it was the copyrights holders' responsibility to search for infringing behaviour. In order to escape liability, intermediaries were only obliged to either identify the subscriber or take down the illicit content after having been noticed by the right holder. ${ }^{29}$ Hence, under the DMCA, intermediaries were in a passive-reactive role and were not required to actively detect copyright-infringing behaviour. However, as Sonia Katyal has shown, a common-law based reinterpretation of ISPs' liability by US courts has asked ISPs to increasingly play a more active role in copyright enforcement. ${ }^{30}$ Although the DMCA does not require intermediaries to actively detect copyright infringements, "a common law trend ... tends to indirectly expand the boundaries of secondary liability for ISPs." 31 As a result, this new case law has been prompting Internet intermediaries to actively employ content-filtering methods to affirmatively search for evidence of infringement in order to protect themselves from secondary liability.

In addition to judicial decisions, three-strike type legislative enactments and industry self-regulation emanating from voluntary collaboration have been major drivers of the paradigm shift in copyright enforcement. Three-strike laws are being debated almost everywhere in the developed world. ${ }^{32}$ The exception is the United States, where Internet intermediaries are cooperating quietly with the entertainment industry. A telling example to illustrate the new collaboration between the entertainment industry and Internet intermediaries in the US are the "Principles for User-Generated Content", which were negotiated between major players of the entertainment industry (including several Hollywood studios and broadcasting networks) and intermediaries (including Crackle, Dailymotion, Microsoft, MySpace,

25 According to Sonia K. Katyal (supra note 11, at p. 420), the Recording Industry Association of America (RIAA) in the last months of 2008 changed its copyright enforcement strategy from law suits (35 000 altogether) to notifying ISPs and calling them to act in their respect.

26 De Beer and Clemmer, supra note 23, at p. 405.

27 According to De Beer and Clemmer (ibid., at p. 386), a notice-and-takedown system exists in almost every jurisdiction where legislation details ISPs' obligations when hosting information.

28 Katyal, supra note 11, at p. 405.

29 De Beer and Clemmer, supra note 23, at p. 385.

30 Katyal, supra note 11, at p. 408.

31 Ibid., at p. 408.

32 The most famous legislative enactment under the new paradigm is the French law "for the distribution and protection of creative content on the Internet" that entered into force on 1 January 2010. This law, known also as "three strikes" law, "graduate response" or "loi HADOPI", is designed to protect business models of the creative economy by sanctioning copyright violations with Internet access cut-offs. HADOPI is the French acronym for the Higher Authority for the Distribution of Works and the Protection of Copyright on the Internet that is in charge of implementing the new law. For a reference to the French "three strikes model" and HADOPI see Jane Winn and Nicolas Jondet, 'A "New Deal" for End Users? Lessons from a French Innovation in the Regulation of Interoperability' (2009) William \& Mary Law Review, 51 (2), pp. 547-576, at pp. 560-561. The first "three strikes" laws were introduced in spring of 2009 in Taiwan and South Korea. See also De Beer and Clemmer, supra note 23, at pp. 389-390 and at p. 393, and Katyal, supra note 11, at p. 409. 
and Veoh). ${ }^{33}$ According to the drafters, the Principles are designed to "foster ... creativity while respecting the rights of copyright owners." 34 The Principles require the operators of sites hosting user-created content (UCC) to utilise filtering and identification technology to block copyright-infringing uploads before they are made public. ${ }^{35}$ Intermediaries subscribing to the Principles are exempt from secondary liability. From a legal perspective, the Principles are non-binding guidelines. Despite their voluntary character, they are regulations that may strongly interfere with users' communicative freedom on the Internet. They are followed by content owners and intermediaries alike because they are the expression of the shared antipathy of both parties toward P2P activities on the Internet. Whereas the content industry perceives file sharing in social networks as a major source of copyright piracy, many intermediaries feel that UCC congests the tubes of the net in a way that will ultimately prevent more lucrative economic development. ${ }^{36}$ According to De Beer and Clemmer "[i]ntermediaries care about network efficiency; copyright holders care about online infringements. File sharing is perceived as a threat to both." 37 Since certain customers would be willing to pay higher rates for preferential distribution, commercial reasons are the main incentive for intermediaries to shape traffic on the Internet. ${ }^{38}$ Accordingly, filtering P2P traffic and distinguishing between commercial and non-commercial content is a shared goal of Internet intermediaries and the entertainment industries.

Self-regulatory activities emanating from collaboration between copyright owners and Internet intermediaries seem to be very dynamic beyond the "Principles". Comcast, for example, has been covertly constraining the flow of data from customers using BitTorrent, a file-sharing service. According to Comcast, this step was necessary because BitTorrent was used to illegally communicate huge files of data, including pirated films. ${ }^{39}$ Since this made the Internet slower, Comcast's other customers had complained to the service provider. Slowdown practices have been used by other ISPs as a reaction to video portals, such as YouTube, and social networks, such as Facebook, which swell the amount of data in the net. ${ }^{40}$

Slowdown practices and other Internet traffic-shaping strategies are in violation of the principle of net neutrality. Net neutrality (sometimes also network neutrality) is a term originally coined by Tim $\mathrm{Wu}^{41}$ which is used to defend the openness and freedom of the Internet architecture. However, the principle of net neutrality stands on shaky legal ground, as recent case law in the US demonstrates. In 2008, the US Federal Communications Commission (FCC) required Comcast to respect net

33 De Beer and Clemmer, supra note 23, at p. 399.

34 See CBS Corporation, DailyMotion, Disney et al., 'Internet and Media Industry Leaders Unveil Principles to Foster Online Innovation While Protecting Copyrights', Press Release (18 October 2007), available at http://www.dailymotion.com/press/CP_principlesofUGC.pdf.

35 See Principles for User-Generated Content Services as quoted by De Beer and Clemmer, supra note 23, at $\mathrm{p}$. 399; and Katyal, supra note 11, at p. 421.

36 Katyal, supra note 11, at pp. 420-421.

37 De Beer and Clemmer, supra note 23, at pp. 405-406.

38 See ibid., at p. 406.

39 Katyal, supra note 11, at pp. 416-417.

40 For further information on notice and slowdown practices see De Beer and Clemmer, supra note 23, at pp. 391-393.

${ }^{41}$ See Tim Wu, 'Network Neutrality, Broadband Discrimination' (2003) Journal on Telecommunications and High Technology Law, 2, pp. 141-179. 
neutrality and prohibited the intermediary from throttling P2P traffic on its network. However, the FCC decision was reversed by the 6 April 2010 decision by the United States Court of Appeals for the District of Columbia Circuit. ${ }^{42}$ The Court of Appeals found that the FCC acted beyond its authority to regulate the Internet and was not allowed to sanction Comcast's network management practices.

Finally, on 9 August 2010, Google and Verizon published an agreement lobbying for Congress to exempt wireless services on the Internet from regulation on net neutrality. This would have the effect of leaving those services open for data discrimination, allowing Verizon to distribute some online content to Internet users more quickly if the content's creators are willing to pay for the privilege. ${ }^{43}$

\subsection{CONSEQUENCES OF THE NEW PARADIGM FROM A COMMUNICATIVE FREEDOM PERSPECTIVE}

When people think of dangers to free speech they usually think of government censorship. What may be right in the offline world is wrong on the Internet. On the Internet, as we have demonstrated above, threats to communicative freedom often stem from private rather than state action. Filtering and traffic management practices are normally a consequence of decisions taken at the level of the architecture of the Internet and this architecture is mostly in the hands of private actors.

From the perspective of free-speech values, the most important implication of the paradigm change in copyright enforcement is certainly the shift from ex post to $e x$ ante methods of surveillance. In the offline world, ex ante surveillance of communication exerted by governments would be considered as censorship and, thus, as something that rips into the heart of communicative freedom. On the Internet, however, where ex ante surveillance is practised by private parties, policymakers and regulators do not seem to be fully aware of the problem and there exists very little substantive judicial oversight or intervention. ${ }^{44}$

Intermediaries surveying the Internet ex ante rely on automated methods to detect copyright infringements. ${ }^{45}$ Because it is difficult to assess whether certain content is fair use, such automated methods are often overbroad. ${ }^{46}$ Automated control tends to over-block and conflicts with the principle of proportionality. ${ }^{47}$ This

42 Comcast v FCC (6 April 2010) USCA 08-1291 (DC Circuit).

43 See 'No, these are special puppies', The Economist (12 August 2010). On 21 December 2010, the FCC set down new rules on Internet traffic management that come close to the agreement between Google and Verizon. The new rules are likely to be challenged in the courts and in Congress. See 'FCC Approves Net Rules and Braces for Fight', New York Times (21 December 2010).

$44 \quad$ Katyal, supra note 11, at p. 416.

45 Often, automated filtering will take place without the user's knowledge. However, as the German Constitutional Court held in its recent data retention judgement (see infra, note 126) non-transparent interferences with data flows may harm users' expectations of the network's confidentiality and integrity and leave users "with a diffusely threatening feeling of being observed that may impede an unbiased exercise of fundamental rights in many areas." (Para. 212, German in the original).

46 For a distinction between manual and automated review in its impact on UCC see Katyal, supra note 11, at p. 422.

47 Thomas J. McIntyre and Colin Scott, 'Internet Filtering: Rhetoric, Legitimacy, Accountability and Responsibility', in Roger Brownsword and Karen Yeung (eds), Regulating Technologies, Oxford: Hart Publishing, 2009, pp. 109-125, at p. 116. The principle of proportionality is well established as a general principle of law in the European countries, in the European Union and in the framework of the European 
amounts to a particular problem for communicative freedom, especially if one considers the impact on UCC of a non-commercial origin. In cases of appropriation of content, including mash-up or remix creations, this uncertainty of what is allowed by fair use "often risks chilling the transformative work of artists who seek to incorporate the work of others." 48

Under the new paradigm, users will often not know that their movements on an Internet intermediary's platform are filtered and - hence - no response against this interference will be available. This is a critical issue from a transparency perspective. In cases where possibilities for consumers to respond to an intervention exist, there is a change in the burden of proof. Whereas under the old paradigm it was the copyright owner who had to prove that a consumer had violated copyright, ex ante surveillance requires consumers wanting to oppose blocking, slowing down or deletion to show that certain content posted on the Internet is legal.

Any shift of piracy surveillance from copyright owners to the intermediaries is particularly dangerous from a free-speech perspective since the interests of the entertainment industry to prompt filtering, as a means of copyright enforcement, converge with the interests of intermediaries to discriminate between types of content on their networks. As we have highlighted above, commercial interests may induce intermediaries to employ even more restrictive controls of P2P traffic. Accordingly, such an alignment of interests directed against P2P and UCC may raise deeper structural concerns about net neutrality and creativity on the Internet. ${ }^{49}$

\section{CREATIVITY, COMMERCIAL INTERESTS AND COMMUNICATIVE FREEDOM IN A CONSTITUTIONAL SETTING}

Creativity has been the magic word in any discussion regarding the protection of intellectual property rights (IPRs) on the Internet in recent years. Amazingly, creativity has been the battle cry on the sides of proponents and opponents of a strong institutionalisation of IPRs alike. On the one side, the entertainment industries successfully lobbied governments to raise the standard of protection of IPRs at the

Convention on Human Rights. In EU law it is enshrined as a general principle in Article 5 of the Treaty on European Union (EU, Treaty on European Union, (30 March 2010) Official Journal of the European Union, C 83, pp. 13-46, at p. 15,) and provides that action by the Union shall not go beyond what is necessary to achieve the objectives of the Treaty. The proportionality principle has been further fleshed out in the case law of the European Court of Justice (ECJ). Before the ECJ, the proportionality principle allows applicants to challenge Union action as well as action by EU Member States that falls within the sphere of application of EU law. It normally requires a Union or government measure to be: 1) suitable; and 2) necessary to achieve the desired end; and 3) to respect reasonable relationship between the measure taken and the objective sought to be achieved. See Paul Craig and Gráinne de Búrca, EU Law, 4th edn, New York: Oxford University Press, 2008, pp. 544-551; and Junko Ueda, 'Is the Principle of Proportionality the European Approach' (2003) European Business Law Review, 14 (5), pp. 557-593. On the proportionality principle in the realm of the European Convention on Human Rights see infra note 124.

48 As Katyal, supra note 11, at p. 412, notes, "an overinclusive approach to piracy surveillance risks not only chilling some forms of valuable speech, but it also risks having a deleterious effect on the technologies that distribute content as well, making it even more costly for new technologies to develop unless they devote substantial resources to the perfection of such strategies."

49 Ibid., at p. 416. 
national ${ }^{50}$ and international level. ${ }^{51}$ The argument was consistently that this is necessary for the sake of creativity and the creative industries on the Internet. ${ }^{52}$ Creativity has also been a central term in the entertainment industries' rhetoric in the context of copyright enforcement - be it in the Recording Industry Association of America's (RIAA) 35000 law suits, ${ }^{53}$ the defence of the above-mentioned 'Principles for User-Generated Content', ${ }^{54}$ or in the debate related to the creation of ACTA, the new international Anti-Counterfeiting Trade Agreement. ${ }^{55}$

On the other side, critics of an overbroad protection of IPRs have been arguing that, in a digital networked environment, creativity depends on an IP system providing for a fair balance between the private interests of right holders and the public interest in enjoining broad access to their productions. According to these views, networked digital technologies have radically changed not only the way in which content is produced, disseminated and consumed, but have also led to the development of participatory technologies, including blogs, social networks, wikis etc. Hence, IPR systems must be flexible enough not to criminalise or suffocate these new expressions of creativity on the Internet.

\subsection{THE PARTICIPATIVE WEB AND THE CHANGE OF COMMUNICATIVE FREEDOM}

The participative web blurred the frontiers between creators and consumers and democratised the production of art. In the view of Jonathan Zittrain: ${ }^{56}$

Today, thanks to networked information technology and the recursively generative code produced in large part by amateurs, art can be produced and shared by people other than professional artists, citizens can engage in far-ranging dialogues with others whom they would not otherwise encounter, and people can work together from the four corners of the globe to produce intellectual projects of social and economic significance.

Jack Balkin argues that the participative web changed the right of free speech. In his view, "the point of free speech is to promote a democratic culture". Democratic culture he understands as ${ }^{57}$

50 In the United States, Congress has lengthened the copyright protection term several times over the last decades. Section 8 of the US Constitution empowers Congress to "promote the progress of science and useful arts, by securing for limited times to authors and inventors the exclusive right to their respective writings and discoveries." What started in the 18th century as a renewable 14-year term now lasts for the life of the artist plus 70 years. For company copyrights it has even been extended to 95 years. See Ruth Towse, 'Copyright and Creativity: An Application of Cultural Economics' (2006) Review of Economic Research on Copyright Issues, 3 (2), pp. 83-91, at p. 88.

51 Internationally copyright has been strengthened above all in the framework of the World Intellectual Property Organization (WIPO) and the Agreement on Trade-Related Aspects of Intellectual Property Rights (TRIPS) of the World Trade Organization (WTO).

52 For references see Towse, supra note 50, at p. 87.

53 Katyal, supra note 11, at pp. 419-420.

54 Supra note 35 and accompanying text.

55 See De Beer and Clemmer, supra note 23, at p. 404.

56 Jonathan Zittrain, 'The Generative Internet' (2006) Harvard Law Review, 119, pp. 1974-2040, at p. 2028.

57 Jack Balkin, 'How Rights Change: Freedom of Speech in the Digital Era' (2004) Sydney Law Review, 26, pp. $5-16$, at p. 8 . 
a culture in which people can participate actively in the creation of cultural meanings that in turn constitute them. A democratic culture is democratic not in the sense that everyone gets to vote on what is in culture. It is democratic in the sense that everyone gets to participate in the production of culture. People are free to express their individuality through creativity and through participation in the forms of meaningmaking that, in turn, constitute them and other people in society.

The value of free speech must be interpreted in a new light because of technological developments in the digital ecosystem. Although the social institutionalisation of this value is similar in most Western societies, there exist differences with regard to its legal institutionalisation as a constitutional right. Dependent on the respective legal order, this right has different names, including, e.g., free speech (US context) or freedom of expression and information (European and international human rights law). For the purpose of the transnational research approach underlying this paper, we will use the term "communicative freedom" as a general term capturing the central features of the right at issue across the mentioned legal orders.

Whereas, in the age of broadcasting, communicative freedom was interpreted by courts as something passive, the participative forms of meaning-making on the Internet would arguably require communicative freedom to be interpreted as an active concept. As an active concept, communicative freedom would acknowledge UCC being a typical new phenomenon of creativity on the Internet. Digital technologies on the Internet offer consumers the possibility of appropriating content produced by mass media, to mash up and remix pre-existing works and to create new forms of content as collages. ${ }^{58}$ Although there is no generally accepted definition of UCC ${ }^{59}$ the central feature of the concept for our context is that amateur users express their creativity by adding something new to pre-existing works, without necessarily respecting the narrow fair-use limits of copyright law. The possibility of UCC, thus, requires redefining the constitutional relationship between the values of communicative freedom and intellectual property.

As Balkin's concept of "democratic culture" suggests, there is a need for the right to free speech on the Internet, not only to protect political communication, but also non-political communication, including popular culture. Judicial authorities have traditionally preferred political speech to "cultural" speech. This is true not only for US First Amendment doctrine ${ }^{60}$ but also for European categorisations in the interpretation of the freedom of expression and information. The reasons for these value judgements date back to the emancipation of the bourgeois society in the 18th

58 Jack Balkin, 'Digital Speech and Democratic Culture: A Theory of Freedom of Expression for the Information Society' (2004) New York University Law Review, 79, pp. 1-55, at p. 9.

59 The OECD's definition of UCC provides three criteria: (i) "content made publicly available over the Internet", (ii) "which reflects a certain amount of creative effort"; and (iii) "which is created outside of professional routines and practices" (OECD, 'Participative Web: User-created Content', (OECD Doc. DSTI/ICCP/IE(2006)7/FINAL, 2007), at p. 9). This definition is also used by the European Commission, see, e.g. CEC, Green Paper, 'Copyright in the Knowledge Economy', (CEC Doc. COM (2008) 466/3), at p. 19.

60 Balkin, 'Digital Speech and Democratic Culture: A Theory of Freedom of Expression for the Information Society', supra note 58 . 
century. ${ }^{61}$ In the age of the participatory web, however, political speech should no longer be preferred to "cultural" speech of netizens. The Internet is a public space ${ }^{62}$ that must not be "propertised" 63 by the entertainment industries to control - by the means of IPRs - how ordinary people use digital content. ${ }^{64}$ Balkin is right that constitutional rights must adapt to this value change and establish a new balance between creativity, as a free-speech value, and the exclusive commercial interests of digital business and the entertainment industries. At the international level, arguments for a reconsideration of the relationship between IP values and freespeech values are supported by the new UNESCO Convention on the Protection and Promotion of the Diversity of Cultural Expressions (CCD). The CCD says more on the relationship between commercial values and cultural values in general than on IP in particular. ${ }^{65}$ Although the CCD suffers from considerable normative weaknesses, ${ }^{66}$ its almost unanimous adoption and the rapid and broad ratification ${ }^{67}$ is a political signal from a large group of governments worldwide that economic values should no longer be preferred to values of creative expression. ${ }^{68}$ Since the CCD affects not

61 As described by Jürgen Habermas in 1962, the liberal model of the bourgeois public sphere emerged in 18 th century Europe as a counterweight to the absolute state. The public sphere was conceived as an arena for debating and deliberating issues of political rather than economic or cultural interest. See Jürgen Habermas, The Structural Transformation of the Public Sphere. An Inquiry into a Category of Bourgeois Society, translation by Thomas Burger and Frederick Lawrence, Cambridge: Polity Press, 2007 (first published in 1962 as "Strukturwandel der Öffentlichkeit"). The idea that free discursive relations in the public sphere constitute the fundament of a democratic society strongly influenced contemporary formulations of constitutional rights protecting freedom of expression and information in Europe. According to the classic formula used by the European Court of Human Rights, "Freedom of expression constitutes one of the essential foundations of a democratic society". See European Court of Human Rights, Handyside v United Kingdom, judgement of 7 December 1976, Series A no. 24, p. 23, para. 49.

62 According to Balkin, 'Digital Speech and Democratic Culture: A Theory of Freedom of Expression for the Information Society', supra note 58, at p. 50: "Communications networks are public in nature even if their technological infrastructure is privately owned. Therefore they must grant fair access to their networks."

63 "Propertisation" has been used in recent socio-legal literature as a term to describe and criticise processes limiting access to commons, public goods and public domains by the means of property-like legal tools in the areas of economics, technology, culture and communication. For an overview see the various contributions in Hannes Siegrist (ed.), Entgrenzung des Eigentums in modernen Gesellschaften und Rechtskulturen, Leipzig: Leipziger Universitätsverlag, 2007.

64 Balkin, 'Digital Speech and Democratic Culture: A Theory of Freedom of Expression for the Information Society', supra note 58 , at pp. 21 and 26.

65 Although the CCD does not address the relationship between IP and values of cultural diversity explicitly, Article 7(1) CCD obliges parties to "create ... an environment which encourages individuals and social groups: (a) to create, produce, disseminate, distribute and have access to their own cultural expressions [and] (b) to have access to diverse cultural expressions from within their territory as well as from other countries of the world". On UCC from a cultural diversity perspective see Mira Burri-Nenova, 'User Created Content in Virtual Worlds and Cultural Diversity', in Christoph Beat Graber and Mira BurriNenova (eds), Governance of Digital Game Environments and Cultural Diversity, Cheltenham, UK: Edward Elgar, 2010, pp. 74-112.

66 For an analysis see Christoph Beat Graber, 'Substantive Rights and Obligations under the UNESCO Convention on Cultural Diversity', in Hildegard Schneider and Peter van den Bossche (eds), Protection of Cultural Diversity from an International and European Perspective, Antwerp: Intersentia, 2008, pp. 141-162.

67 The CCD, which entered into force on 18 March 2007 (available at http://portal.unesco.org/la/convention.asp?KO=31038\&language=E\&order=alpha), has been ratified as of 1 August 2010 by more than 110 countries.

68 Christoph Beat Graber, 'Trade and Culture', in Rüdiger Wolfrum (ed.), The Max Planck Encyclopedia of Public International Law, Oxford: Oxford University Press, 2010, online edition, available at www.mpepil.com. 
only the external relations of a state party but also its internal ones, it needs to undertake measures contributing to the attainment of the goal of protecting and promoting cultural diversity in order to fulfil its obligations under the Convention.

\subsection{COMMUNICATIVE FREEDOM AND THE NETWORK GRID}

It is an important step for constitutional theory to postulate that the technological changes of the participative web bring particular features of communicative freedom to the forefront, requiring a re-evaluation of the relationship between political and cultural speech within a constitutional setting. This, however, is not sufficient. As we have argued above, on the Internet, implications of code must be considered as potential threats to free-speech values in addition to implications of an overbroad IP system. Accordingly, considerations over communicative freedom on the Internet must also encompass the specific technological implications of networked digital communication. As the discussion on network neutrality shows, the openness and freedom of the Internet directly depend on decisions taken at the level of the technological architecture. ${ }^{69}$ Technology is used to differentiate between various data transmissions and to make the quality and speed of the transmitted information contingent on financial rates of return or other unilaterally set criteria. Network neutrality has been used during recent years as a slogan to combat any such models and to convince regulators that the network should stay neutral to the passing content. ${ }^{70}$ Whereas the legal basis of the concept has been contested by a district court in the US, ${ }^{71}$ the European Union has included network neutrality as a policy objective and regulatory principle in Directive 2009/140/EC, ${ }^{72}$ amending the European Union's package of communication law, including the framework, access and authorisation directives. In an annex, Directive 2009/140/EC provides for a "Commission declaration on net neutrality" that reads as follows:

The Commission attaches high importance to preserving the open and neutral character of the Internet, taking full account of the will of the co-legislators now to enshrine net neutrality as a policy objective and regulatory principle to be promoted by national regulatory authorities, alongside the strengthening of related transparency requirements and the creation of safeguard powers for national regulatory authorities to prevent the degradation of services and the hindering or slowing down of traffic over public networks. The Commission will monitor closely the implementation of these provisions in the Member States, introducing a particular focus on how the "net freedoms" of European citizens are being safeguarded in its

69 According to Balkin, 'Digital Speech and Democratic Culture: A Theory of Freedom of Expression for the Information Society', supra note 58, at p. 50, communication networks "must grant fair access to their networks, they must not act as chokepoints or bottlenecks, and they must not unfairly discriminate against content from other sources."

70 See Susan P. Crawford, 'Network Rules' (2007) Law and Contemporary Problems, 70, pp. 51-90, at p. 51; Wu, supra note 41 , at p. 141.

71 See supra note 42 , and accompanying text.

72 EC, Directive 2009/140/EC of the European Parliament and of the Council of 25 November 2009 amending Directives 2002/21/EC on a common regulatory framework for electronic communications networks and services, 2002/19/EC on access to, and interconnection of, electronic communications networks and associated facilities, and 2002/20/EC on the authorisation of electronic communications networks and services, (18 December 2009) Official Journal of the European Union, 337, pp. 37-69. See recitals 34-38 and 40. 
annual Progress Report to the European Parliament and the Council. In the meantime, the Commission will monitor the impact of market and technological developments on "net freedoms" reporting to the European Parliament and Council before the end of 2010 on whether additional guidance is required, and will invoke its existing competition law powers to deal with any anti-competitive practices that may emerge.

Since Directives must be implemented by EU Member States at the level of domestic legislation, the principle is not self-executing. The Commission made it clear, however, that it will closely monitor how Member States implement this principle. In addition, the Commission has announced its willingness to use its competition law powers to ensure adherence to the principle in competitive relationships between market players.

Zittrain has criticised the concept of network neutrality as still not being sufficiently comprehensive. ${ }^{73} \mathrm{He}$ argues that the discussion on freedom of the Internet must not be limited to constraints of network connectivity and protocols, but must include any information technology systems involved between PC and PC. ${ }^{74}$ The PC and the Internet are so inextricably intertwined that it is "not enough for network engineers to worry only about network openness and assume that the endpoints can take care of themselves." 75 Hence, in addition to the network itself, it is important to look also at the endpoints. ${ }^{76}$ In his view, end-to-end neutrality does not fully capture all aspects that safeguarding Internet freedom would require to be taken into account. Consequently, the distinction between middle and endpoints, which underlies the rhetoric of end-to-end neutrality, should be replaced with the concept of Internet generativity: ${ }^{77}$

It remains correct that from a network standpoint, protocol designs and the ISPs that implement them are the "middle" of the network, as distinct from PC "endpoints". But the true import of a vernacular of "middle" and "endpoint" for policy purposes relates to individuals' power to control their experiences on the network. ... Now that the network's endpoints are controllable by faraway entities, abandoning the end-toend debate's simplistic divide between middle and endpoint will enable us to identify and respond better to the emerging threats to the Internet's generativity.

The term "Internet generativity" stands for the potential of individual Internet users to creatively tinker with the technology of both their PC and the network. Internet generativity can be endangered by so-called trusted systems, that is, by decisions taken at the level of code. ${ }^{78}$ Hence, in the networked digital environment, social spheres of action are determined by technology. As Vagias Karavas argues, technological media pre-structure the social sphere of action, "thus transforming the whole social sphere into a hybrid entity of technosocial character" ${ }^{79} \mathrm{He}$ argues that

73 Zittrain, 'The Generative Internet', supra note 56, at p. 2029.

$74 \quad$ Ibid., at p. 1978.

$75 \quad$ Ibid., at p. 2031.

76 Jonathan Zittrain, The Future of the Internet and How to Stop It, New Haven: Yale University Press, 2008, at p. 8 .

77 Zittrain, 'The Generative Internet', supra note 56, at p. 2031.

78 Zittrain, 'The Future of the Internet and How to Stop It', supra note 76, at p.105.

79 Vagias Karavas, 'The Force of Code: Law's Transformation under Information Technological Conditions' (2009) German Law Journal, 10 (4), pp. 463-481, at p. 471; see also Vagias Karavas, Digitale Grundrechte. Elemente einer Verfassung des Informationsflusses im Internet, Baden-Baden: Nomos, 2007, at p. 155. 
on the Internet basic constitutional rights can no longer be conceived as existing only in a sphere of normative communication independent from technology. Arguably, the law's dependency on technological media paves the way for the emergence of what Karavas calls "technodigital normativity", that is "the amalgamation of normative and digital expectations inside the digital medium" ${ }^{80}$ For Karavas, the specific function of basic rights on the Internet consists of safeguarding the integrity of digital systems. The German Constitutional Court has come to a similar conclusion in a recent leading case. In the judgement, resulting in the annulment of legislation regulating online investigations, the Court developed unwritten constitutional guarantees protecting "the integrity and confidentiality of information technology systems". ${ }^{81}$ Inspired by Bruno Latour, Karavas has lately argued that protecting the integrity of information technology systems would also encompass an "associative link" between creative user activities (so-called Web 2.0 activities) and the information technology system. ${ }^{82}$

To conclude, communicative freedom must also protect the integrity of the technological architecture. The "technodigital normativity" of the Internet requires conceiving the possibility to creatively communicate on the Internet as being inextricably intertwined with the technology of the network grid.

\section{Constitutional Rights in the Private Sphere of THE INTERNET}

So far we have discussed how communicative freedom has changed in order to fully protect new aspects that come to the surface of the constitutional right. What remains is the problem that many of the threats to free-speech values that we emphasised originate in private action, whereas constitutional rights can only be applied in cases of state action. It is a common feature of classic constitutional doctrine, both in the US and in European legal orders, that constitutional rights are perceived as applying exclusively in relationships between a private person and the state. In Europe, the classic formulation of constitutional rights views these rights as individual defences against the intrusive power of the state. Although the German Constitutional Court has been developing, step by step, an institutional formulation of constitutional rights, since the end of World War II, there has been a strong countermovement defending the classic doctrine. ${ }^{83}$ In the United States, the

80 Karavas, 'The Force of Code: Law's Transformation under Information Technological Conditions', supra note 79 , at p. 478

81 Bundesverfassungsgericht, 1 BvR 370/07, 1 BvR 595X/07, 27 February 2008, at paras 201, 203, 207 (German in the original).

82 Vagias Karavas, 'Grundrechtsschutz im Web 2.0: Ein Beitrag zur Verankerung des Grundrechtsschutzes in einer Epistemologie hybrider Assoziationen zwischen Mensch und Computer', in Christoph Bieber, Martin Eifert, Thomas Gross and Jörn Lamla (eds), Soziale Netzwerke. Das Internet zwischen egalitärer Teilhabe und ökonomischer Vermarktung, Frankfurt: Campus Publishers, 2010 (forthcoming), pp. 301-325 (German in the original). See also Thomas Steiner, Advertising in Online Games and Cultural Diversity. An EC and International Media Law Enquiry, Bern: Stämpfli, 2010, at p. 69.

83 Christoph Beat Graber and Gunther Teubner, 'Art and Money: Constitutional Rights in the Private Sphere' (1998) Oxford Journal of Legal Studies, 18, pp. 61-73, at p. 63; Karl-Heinz Ladeur, 'Die Drittwirkung der Grundrechte im Privatrecht - "Verfassungsprivatrecht" als Kollisionsrecht', in Gralf-Peter Calliess et al. 
possibility of a constitutionally based oversight in the private sphere is limited by the so-called "state action" doctrine. Although the state action doctrine has shifted over time since its first formulation in an 1883 Supreme Court decision, it still rests on an interpretation of the US Constitution to proscribe only the conduct of government agencies in most of its commandments. ${ }^{84}$ In Shelley $v$. Kraemer, the Supreme Court held that "... the Constitution erects no shield against merely private conduct, however discriminatory or wrongful" ${ }^{85}$ In cases where a clear demarcation between private and public conduct is difficult, courts have often looked at either "whether the private party is performing a public function" or whether the action of a private party is so closely linked to the government that it is attributable to the state for constitutional purposes. ${ }^{86}$

Although scholarship in the US has been busy attacking the public/private distinction underlying the state action doctrine for decades, ${ }^{87}$ it has been unable to dismantle it. Rather than adding to these criticisms, Paul Schiff Berman proposed an alternative approach that he calls "constitutive constitutionalism". According to his view, the debate "should focus on the Constitution's constitutive role in our cultural life, regardless of whether that life is lived in the public or private sphere." 88 When adjudicating conflicts between private parties, courts should transform into a forum for debating core societal values. ${ }^{89}$ In cases where such values are endangered by private action, courts would be required to conduct a broader discussion over these values. We agree with Berman, that requiring an element of state action misses the point of why constitutional rights should play a role in the private sphere. Rather than asking whether a state act was involved directly or indirectly, the relevant criterion should be "effective infringement of individual or social autonomy whatever its source". ${ }^{90}$ Berman uses examples of private powers employing code to regulate behaviour on the Internet to support his argument. ${ }^{91}$ We agree that these examples demonstrate convincingly that subjecting private standard-setting powers to constitutional review is necessary for securing individual and social autonomy on the Internet. However, we join Karavas in his critique that Berman's approach is too vague and that it would make people believe that constitutional law and constitutional courts can resolve any societal conflict. ${ }^{92}$ Berman concedes that courts

(eds), Soziologische Jurisprudenz. Festschrift für Gunther Teubner zum 65. Geburtstag, Berlin: De Gruyter, 2009, pp. 543-558.

84 Bellia, Berman and Post, supra note 20, at pp. 328-329.

85 Shelley $v$ Kraemer (1948) 334 US 1, 13.

86 Bellia, Berman and Post, supra note 20, at p. 329.

87 For a general critique of the public/private distinction see Christine Chinkin, 'A Critique of the Public/Private Dimension' (1999) European Journal of International Law, 10 (2), pp. 387-395; Duncan Kennedy, 'The Stages of the Decline of the Public/Private Distinction' (1982) University of Pennsylvania Law Review, 130 (6), pp. $1349-1357$.

88 Berman, supra note 19 , at p. 1289.

89 Berman, ibid., at pp. 1296-1298.

90 Graber and Teubner, supra note 83 , at p. 70. For a more comprehensive elaboration of this argument see chapter 5.1 below.

91 Berman, supra note 19, at p. 1307.

92 Karavas, 'Digitale Grundrechte. Elemente einer Verfassung des Informationsflusses im Internet', supra note 79 , at p. 64 . 
are not the only possible forum for articulating fundamental societal values. ${ }^{93}$ Nonetheless, he is convinced that "they may sometimes provide a more satisfying resolution than the political process can." 94

From a transnational law perspective it is interesting to note that in Germany a direct effect of basic rights of the Grundgesetz has been rejected mainly because it does not fit in with the dominant doctrine's view of basic rights as tools designed to fight asymmetries of power (which, arguably, only exist in relationships between individual and state). ${ }^{95}$ Similarly, a direct horizontal effect of basic rights of the constitution has also been continually and unanimously rejected by courts and academia in Switzerland. The main concern here was that a direct effect would lead to a shift of power from the political authorities to the judiciary. However, as a result of a general constitutional reform in 1999, Article 35(3) of the Swiss Constitution requires authorities to "ensure that fundamental rights, where appropriate, apply to relationships among private persons." 96 This provision has consistently been interpreted as establishing an indirect horizontal effect of basic rights of the Constitution. ${ }^{97}$

As Graber and Teubner have argued, the major shortcoming in the European debate on basic constitutional rights in the private sphere is "the narrow view that these rights are constituted exclusively in a triad of individual-power-State." This is due to "an unholy alliance between liberal political philosophy and the procedures of public law." ${ }^{98}$ Liberal political philosophy is based on a concept of the state as a (social) contract between citizens. As a central element of this contract, citizens confer on the state the monopoly in the exercise of power. At the same time, they reserve basic individual rights defining a quasi-spatial exclusion zone against state intervention. The relationship of state and society is understood as a dichotomy. Cooriginality of private and public autonomy is the term Jürgen Habermas coined to describe the sociological observation that basic rights and the state have the same normative origin. ${ }^{99}$ The state-centrism of this concept was bolstered up by the procedures of public law, placing particular procedures at the individual's disposal, which are necessary for the enforcement of his/her basic rights against the state.

The view that basic rights of the constitution are directed against the state was challenged by Graber and Teubner using a socio-legal approach based on Niklas

93 Berman, supra note 19, at p. 1268 (discussing drawbacks of an extension of the scope of state action as a strategy to subject more private activities to constitutional scrutiny).

$94 \quad$ Ibid., at p. 1298.

95 According to Karavas, supra note 79, at p. 64, Berman's approach closely resembles the doctrine of the German Constitutional Court stating that the basic rights of the constitution include an objective dimension and must be observed throughout the legal order. Karavas has systematically reconstructed the debate in Germany and Switzerland on constitutional rights in the private sphere (also called "horizontal effect" of constitutional rights) and compared it to the US debate on the state action doctrine.

96 Federal Constitution of the Swiss Confederation of 18 April 1999 (Status as of 27 September 2009), available online at http://www.admin.ch/ch/e/rs/1/101.en.pdf.

97 Bernhard Ehrenzeller, Philippe Mastronardi, Rainer J. Schweizer and Klaus A. Vallender (eds), Die Schweizerische Bundesverfassung, 2nd edn, Zürich: Dike and Schulthess, 2008, notes on Article 35 of the Swiss Constitution, notes 35-37 on Article 35 of the Swiss Constitution.

98 Graber and Teubner, supra note 83, at p. 63

99 Habermas, 'Between Facts and Norms. Contributions to a Discourse Theory of Law and Democracy', supra note 15 , at p. 104. This formula leaves no space for forms of legal autonomy that are neither exclusively public nor exclusively private. For a critique see Gralf-Peter Calliess, Prozedurales Recht, Baden-Baden: Nomos, 1999, at pp. 186-187. 
Luhmann's system theory. If one analyses the coming into being of basic rights from a perspective of sociological jurisprudence, one first has to note that basic rights are a typical phenomenon of the modern, i.e. functionally differentiated, society. In premodern segmented or stratified societies, the idea of an autonomous individual did not exist. ${ }^{100}$ Until the end of the 18th century, the formula for social relations was status and not (individual rights based) contract. ${ }^{101}$ Consequently, rather than a constitution vesting basic rights in a person, it was the clan, the family or the social stratum constituting rights, obligations and opportunities of its members. In the course of the process of social differentiation eventually leading to modernity, distinct spheres of social autonomy emerged. The autonomy of the individual was only one among many newly differentiated social spheres, including the functionally differentiated systems of law, politics, economics, science, art etc. In Luhmann's theory, a "system" can be understood as a distinct discourse where a specific "language game" (i.e. law, politics, economics etc.) is practised according to autonomously generated "grammatical" rules. To protect the autonomy of these spheres of action, modern society invented basic rights as social institutions. Basic rights are, thus, first and foremost social institutions and must be distinguished from basic rights as legal institutions. As social institutions, the function of basic rights is to protect functional differentiation against self-destroying tendencies of modern society. ${ }^{102}$ Hence, it is not only the autonomous sphere of the individual, but rather the autonomous spheres of all functionally differentiated systems of modern society that must be protected by basic rights. This distinction between basic rights as social institutions and basic rights as legal institutions represents the main difference between a Luhmanian institutional and a classic concept of basic rights. Although it is the social institution of constitutional rights that protects social autonomy, it is the role of the law to stabilise these rights and to shape them to a certain degree. ${ }^{103}$ The focus on both individual and trans-individual (discursive) situations is the first of two important implications of an institutional understanding of basic rights. The second implication is that basic rights are not only directed against the state, since freedom in modern society can be endangered by any expansionist tendencies of a social system. The fact, thereby, that in the 19th and in the first half of the 20th century, expansionist tendencies in Western societies mainly originated in activities from the political system (i.e. the state) is a mere historic coincident. Experiences from the late 20th and the beginning of the 21st century show that colonising tendencies more often emanate from the economy and from science.

\footnotetext{
100 Niklas Luhmann, Grundrechte als Institution, Berlin: Duncker \& Humblot, 1965, at pp. 33-37; Luhmann, 'Law as a Social System' supra note 8, at pp. 412-419.

101 According to Sir Henry Maine's famous thesis, expressed in 1861, "the history of progressive societies had hitherto been one of a movement from social relations based on status to relations of contract". Quoted from Cotterrell, supra note 5, at p. 119.

102 Graber and Teubner, supra note 83, at p. 65

$103 \quad$ Ibid., at p. 72.
} 


\section{IMPLEMENTING COMMUNICATIVE FREEDOM ON THE INTERNET}

\subsection{THEORETICAL REFLECTION}

We have so far been arguing that, due to a curtailed concept of basic rights, classic constitutional doctrine is unable to properly respond to threats to communicative freedom emanating from networked digital technology in the hands of private actors. Our analysis revealed two reasons for this limited perspective: first, blindness of interdependencies between speech, creativity and technology; and, second, blindness with regard to the function of basic rights as guarantees of communicative chances. ${ }^{104}$ As a response, we first suggested that communicative freedoms of the constitution be interpreted as extending to creative Web 2.0 activities, while taking account of their specific technosocial character. Second, we suggested overcoming the state-centrism of the classic constitutional rights doctrine by introducing a distinction between basic rights as social institutions and basic rights as institutions of the law. An institutional approach to basic rights allows protecting trans-individual discursive values of communicative freedom, even where it is not moulded into the legal form of a "right".

The question now is how these ideas could be brought into effect. We suggest a procedural implementation strategy consisting in a "proceduralisation" of basic rights - a logical consequence of an institutional approach. As Graber and Teubner have suggested, a "proceduralisation" of basic rights would result in introducing legal procedures effectively securing a diversity of autonomous discursive spheres. ${ }^{105}$ This argument is based on Luhmann's above outlined theoretical assumption that basic rights - as institutions - are guarantees for the autonomy of the various subsystems of society. ${ }^{106}$ Whereas from an analytical perspective, basic rights and society exist and develop in a relationship of mutual observation and co-evolution, ${ }^{107}$ from a normative perspective, basic rights protect societal differentiation. ${ }^{108}$ Referring to our discussion in chapter 3.1 above, this is an argument supporting Balkin's postulate for a better constitutional balance between commercial values and freespeech values and against a property-tied interpretation of communicative freedom on the Internet. ${ }^{109}$

Sure enough, a proceduralisation of basic rights on the Internet goes beyond a rebalancing of key social values in a constitutional order. If basic rights have an institutional effect then the law must provide remedies to protect the autonomy of the various individual and social spheres involved. In reality, autonomous spheres of action are often neither exclusively private nor public. Boundaries between private and public autonomies are regularly blurred where public duties are performed by

\footnotetext{
104 Luhmann, 'Grundrechte als Institution', supra note 100, at p. 23.

105 Graber and Teubner, supra note 83, at pp. 72-73.

106 Luhmann, 'Grundrechte als Institution', supra note 100.

107 Christoph Beat Graber, Zwischen Geist und Geld. Interferenzen von Kunst und Wirtschaft aus rechtlicher Sicht, Baden-Baden: Nomos, 1994, at p. 190.

108 Graber and Teubner, supra note 83, at p. 65

109 For a similar argument, see Balkin, 'How Rights Change: Freedom of Speech in the Digital Era', supra note 57 , at p. 46 .
} 
private actors. ${ }^{110}$ Internet intermediaries are a good example of this. Although they are legally organised as private companies they clearly perform public duties, and with regard to content filtering or speed throttling there can be no doubt that both practices interfere with individual and social spheres.

The classic remedies that are made available by the procedures of public law for bringing basic rights into effect mostly rely on the judge. This is problematic on the Internet. Jack Balkin rightly emphasised that the free-speech values he postulated for the Internet "won't necessarily be protected and enforced through judicial creation of constitutional rights". 111 This statement is confirmed by the cases of invisible content filtering and traffic management practised by Internet intermediaries. Here, a decision by a judge would either not be available because of reservations about an extension of judicial power at the expense of legislative power or would not provide a sufficient remedy to effectively protect the private and public interests involved. On the Internet, moreover, the specific features of its technodigital normativity must be protected. The protection of the autonomy (integrity) of the network grid would require procedural responses that take action at the level of the technological infrastructure. Hence, beyond classic remedies securing due process and judicial response, legislative and administrative schemes of regulation would be necessary that protect the integrity of the networked digital environment through framework requirements regulating the design of technological infrastructure.

With respect to the specific constitutional rights implications of technology-based filtering and discrimination of data transmission, protecting the netizen's confidence in the integrity of the network grid must be a central postulate. Because it is essential that the user knows when his/her communication is "regulated", the law should require transparency and prohibit any filtering and content discrimination technologies that come invisibly. ${ }^{112}$ From a due process perspective, feedback and judicial review mechanisms would be important to correct technical and other failures. ${ }^{113}$ Regarding the relationship between IP and technology, we have observed, above, a widening gap between what the law permits and what a "technology intermediated" content market tolerates. ${ }^{114}$ Since it is often difficult to determine what falls under fair use, from a constitutional perspective, it is particularly problematic if piracy surveillance is delegated from the content owners to Internet intermediaries using automated technologies to filter Internet platforms ex ante. ${ }^{115}$ Automated filtering technologies are able to cope with rules but unable to cope with standards such as fair use. ${ }^{116}$ This creates uncertainties that - as we have argued above - in many ways have detrimental effects on Web 2.0 activities and creativity on the Internet. ${ }^{117}$ To enhance legal certainty and to better protect fair-use rights,

110 Calliess, supra note 99, at p. 188.

111 Balkin, 'Digital Speech and Democratic Culture: A Theory of Freedom of Expression for the Information Society', supra note 58 , at p. 51.

112 See Berman, supra note 19, at p. 1275.

113 Katyal, supra note 11, at p. 425.

114 Ibid., at p. 411, addressing the problem of excluding legal mash-ups through filter technology.

115 For the problems of ex ante methods of surveillance from a free speech perspective see supra note 45 , and accompanying text.

116 Katyal, supra note 11, at pp. 411-413.

117 Ibid., at p. 412, arguing that uncertainties over what constitutes fair use "risks chilling the transformative work of artists who seek to incorporate the work of others". 
procedures which liberate the consumer from the burden of proof would, thus, be important when issues related to distinguishing between legal and illegal use of content arise.

\subsection{PRACTICAL SOLUTIONS}

With regard to practical implementation it seems that some kind of governmentassisted regulation would be necessary to secure the public policy goals that are at stake. In this context, it is interesting to note that the Electronic Frontier Foundation (EFF) called for a "three strikes before blocking" rule, arguing that such a model appears to be something more consumer-friendly than the self-regulatory instruments. ${ }^{118}$ In our view, this claim must be understood against the background of the specific situation in the US where voluntary copyright enforcement agreements between content owners and Internet intermediaries proliferate. ${ }^{119}$ In Europe, "three strikes and you are out" solutions are less acclaimed as the heated public debate surrounding the French "loi HADOPI" and the ruling of the Constitutional Council against a first draft of the act demonstrated. ${ }^{120}$

Under the influence of a Council of Europe Resolution on freedom of expression (Article 10 of the European Convention on Human Rights) and Internet filtering, ${ }^{121}$ the European Union was more sensitive to communicative freedom when it adopted at the end of 2009 the new EC Directive 2009/140/EC (Umbrella Directive), ${ }^{122}$ amending the framework, access and authorisation directives of the Union's communications framework. Article 1 (3a) Framework Directive (as amended by the Umbrella Directive) ${ }^{123}$ provides for a "Freedom Provision":

Measures taken by Member States regarding end-users' access to, or use of, services and applications through electronic communications networks shall respect the fundamental rights and freedoms of natural persons, as guaranteed by the European Convention for the Protection of Human Rights and Fundamental Freedoms and general principles of Community law. Any of these measures regarding end-users' access to, or use of, services and applications through electronic communications networks liable to restrict those fundamental rights or freedoms may only be imposed if they are appropriate, proportionate and necessary within a democratic society, and their implementation shall be subject to adequate procedural safeguards in conformity with the European Convention for the Protection of Human Rights and

$118 \quad$ Ibid., at pp. 421-422.

119 See supra note 35, and accompanying text.

120 Constitutional Council, Decision No. 2009-580 DC of 10 June 2009, Act Furthering the Diffusion and Protection of Creation on the Internet, Journal Official (13 June 2009), p. 9675. (English translation available at http://www.conseil-constitutionnel.fr/conseil-constitutionnel/root/bank_mm/anglais/2009_580dc.pdf). For a discussion of the decision see Pierre Sirinelli, 'The Graduated Response and the Role of Intermediaries', in Lionel Bently et al. (eds), Global Copyright, Cheltenham, UK: Edward Elgar, 2010, pp. 478-491. After the Constitutional Court turned down a new complaint against an amended version of the legislation in Decision no. 2009-590 DC of 22 October 2009, the "loi HADOPI" entered into force on 1 January 2010.

121 Recommendation CM/Rec(2008)6 of the Committee of Ministers to Member States on measures to promote the respect for freedom of expression and information with regard to Internet filters, adopted by the Committee of Ministers on 26 March 2008.

122 EC, Directive 2009/140/EC, supra note 72.

123 See ibid., Article 1(1)(b). 
Fundamental Freedoms and with general principles of Community law, including effective judicial protection and due process. Accordingly, these measures may only be taken with due respect for the principle of the presumption of innocence and the right to privacy. A prior, fair and impartial procedure shall be guaranteed, including the right to be heard of the person or persons concerned, subject to the need for appropriate conditions and procedural arrangements in duly substantiated cases of urgency in conformity with the European Convention for the Protection of Human Rights and Fundamental Freedoms. The right to effective and timely judicial review shall be guaranteed.

As far as access to and use of networks is concerned, this provision takes account of several of our postulates for effectively protecting communicative freedom on the Internet, including the presumption of innocence, feedback procedures, due process and judicial review. We emphasise that the "freedom provision" opts for a procedural framework, which must be implemented by Member States, rather than providing for a substantive rule. With a view to the sometimes rather competitive relationship between the EU and the Council of Europe in matters of human rights, it is interesting to note that the freedom provision directly refers to the "adequate procedural safeguards" and the proportionality test provided by the European Convention on Human Rights (ECHR). ${ }^{124}$ Concerns of proportionality were the major reason for many to object to the "graduated response" of the French "loi HADOPI" providing for an Internet cut-off after the third copyright-infringing activity on the network. ${ }^{125}$ Since Internet access is of extreme importance for most individuals today, a definitive Internet cut-off seems to be an overly severe response to a copyright infringement.

A further interesting feature of this clause is its reference to the right to privacy. Private filtering as a strategy for copyright enforcement requires the collection of huge amounts of sensitive consumer data. Courts have recently become more sensitive with regard to basic-rights implications of such data collection, as a 2 March 2010 landmark judgement of the German Constitutional Court demonstrates. ${ }^{126}$ In

124 The proportionality test as applied by the European Court of Human Rights in the context of restrictions to fundamental rights generally consists of three stages: 1) Is the challenged measure suitable to achieve a legitimate objective? 2) Is the measure necessary in order to achieve that objective? 3) Is there a reasonable relationship between the measure and the desired aim (proportionality stricto sensu)? Article 10 ECHR (freedom of expression and information) provides in paragraph 2 an exhaustive list of legitimate objectives, including national security, territorial integrity, public safety, the prevention of disorder or crime, the protection of health or morals, the protection of the reputation and the rights of others. See John J. Cremona, 'The Proportionality Principle in the Jurisprudence of the European Court of Human Rights', in Ulrich Beyerlin (ed.), Recht zwischen Umbruch und Bewahrung: Völkerrecht, Europarecht, Staatsrecht, Festschrift für Rudolf Bernhardt, Berlin: Springer, 1995, pp. 323-330; and Jeremy McBride, 'Proportionality and the European Convention on Human Rights', in Evelyn Ellis (ed.), The Principle of Proportionality in the Laws of Europe, Oxford: Hart Publishing, 1999, pp. 23-36. On the proportionality test as applied by the European Court of Human Rights when adjudicating intellectual property disputes under the ECHR's property rights clause see Laurence R. Helfer, 'The New Innovation Frontier? Intellectual Property and the European Court of Human Rights' (2008) Harvard International Law Journal, 49 (1), pp. 1-52.

125 See Sirinelli, supra note 120.

126 Bundesverfassungsgericht, BVerfG, 1 BvR 256/08, 2 March 2010, available online at http://www.bverfg.de/entscheidungen/rs20100302_1bvr025608.html. For an appraisal of the case in context of the EU Data Retention Directive that was implemented by the contested provision of the German Telecommunications Act see Christian De Simone, 'Pitting Karlsruhe Against Luxembourg? German Data 
this case, the German Constitutional Court found that certain provisions of the German Telecommunications Act (GTA) allowing preventive data retention by government authorities for a period of six months violated the right to confidentiality of telecommunications as protected by the German Grundgesetz. The contested provisions were enacted by the German legislator to implement the EU Data Retention Directive into national law. ${ }^{127}$ It is particularly noteworthy that the data retention allowed by the GTA was limited to traffic data ${ }^{128}$ and did not extend to content data.

In its reasoning, the Court clarified that under any circumstances a statute allowing for preventive data retention would only be constitutional if the purposes of that law would be limited to the prosecution of crimes that threaten overwhelmingly high-ordered interests of public welfare. ${ }^{129}$ According to the Court, such high-ordered interests of public welfare include physical safety, life, or liberty of persons, security of the federal or state governments and prevention of considerable public danger. ${ }^{130}$ Furthermore the danger to these interests must be sufficiently concrete in order to justify preventive data collection. ${ }^{131}$ This ruling is an unequivocal signal that any massive data retention as implied by a "three strikes and you are out" type of law would not be constitutional in Germany.

\section{CONCLUSIONS}

A law and society approach is useful for finding adequate responses to challenges to communicative freedom on the Internet, arising from new technologies such as Deep Packet Inspection and other forms of automated content filtering. In terms of a classic interpretation of basic rights of the constitution, whereas these rights can be invoked when such measures are deployed by governments, no such remedy is available where private companies, such as Internet intermediaries, use filter technologies to eliminate undesired content or throttle the distribution of data that is not of commercial interest. Such a classic interpretation of basic rights of the constitution, however, must be criticised from a law and society perspective since it neglects that constitutional rights are not only institutions of the law but also - and foremost - institutions of society. Constitutional rights as social institutions fulfil a particular function in society, consisting in the protection of a multitude of individual and social autonomies against self-destroying tendencies within society. The colonisation of non-commercial spheres of Internet communication and

Protection and the Contested Implementation of the EU Data Retention Directive' (2010) German Law Journal, 11 (3), pp. 291-317.

127 EC, Directive 2006/24/EC of the European Parliament and of the Council of 15 March 2006 on the retention of data generated or processed in connection with the provision of publicly available electronic communications services or of public communications networks and amending Directive 2002/58/EC, (13 April 2006) Official Journal of the European Union, 105, pp. 54-63.

128 Traffic data included information necessary to identify the originator and recipient of communications, information identifying the communication equipment used, the time, duration, and date of communications, and real time geographic coordinates of mobile devices during mobile communications. Bundesverfassungsgericht, supra note 126, at para. 192.

129 Ibid., at para. 227.

130 Ibid., at para. 231.

$131 \quad$ Ibid., at para. 232 
creativity by the economy is an example of such a self-destroying tendency, emanating from an expanding system of society. Taking account of the double nature of constitutional rights as institutions of society and institutions of the law, calls for a proceduralisation of constitutional rights. To proceduralise communicative freedom on the Internet means to create legal procedures that protect the plurality of individual and social autonomies in society. The example of Internet filtering demonstrates that waiting for the judge would not be sufficient. Measures for the protection of communicative freedom on the Internet must kick in at an earlier stage to be effective. What is required is a regulatory framework assuring transparency, presumption of innocence, judicial response and due process. Moreover, framework requirements would be necessary to regulate the design of the technological infrastructure where this is necessary to protect the associative link between creative user activities and the integrity of digital systems. 